\title{
The Effects of Rearing Feeder Cattle in Moun- tainous Regions on Organs and on Carcass and Meat Composition after Finishing
}

\author{
Kyohei Ozutsumi, Mitsuo OKada*, Toshio Yamazaki, \\ Naomi KaWaKami and Minoru Usur
}

National Grassland Research Institute, Nishinasuno-cho, Tochigi-ken 329-27

*Obihiro University, Obihiro-shi 080

(Received November 11, 1981)

\begin{abstract}
In order to investigate the effects of rearing feeder cattle in mountainous regions on the weight of organs, carcass characteristics and meat composition after finishing, a comparison was made between 11 Holstein steers finished indoors after grazing on pasture in a mountainous region and 10 Holstein steers reared and finished indoors on low land. All the steers" were slaughtered when their live weight reached approximately $600 \mathrm{~kg}$. The heart, spleen, diaphragma and stomachs of mountain-grazed steers were significantly heavier than those of indoor-reared steers $(P<0.01)$, while small intestines and omentum of indoor-reared steers were significantly heavier than those of mountaingrazed steers $(P<0.05)$. The average bone weight of mountain-grazed steers was greater than that of indoor-reared steers $(P<0.01)$. No significant differences were found in average weights of lean and fat of half carcasses between the groups. There was no significant difference in meat composition between the groups.
\end{abstract}

Jpn. J. Zootech. Sci., 53 (8): $553-558,1982$

Currently, mountainous regions are being considered as a place for cattle grazing, since beef must be produced economically and efficiently in this country.

Changes in weights of organs, carcass and meat composition in cattle through the growth process have been studied by many investigators from different points of view $^{1-9}$. However, relatively little information has been published on the effects of rearing feeder cattle on pasture in mountainous regions on their subsequent beef productivity, except for the report of SAWAZAKI et al. ${ }^{10)}$. It is necessary to find out the effects of mountain grazing on cattle productivity in order to make mountainous grazing for cattle in this country efficient.

\section{Materials and Methods}

Eleven Holstein steers (MG group) were fattened under housed conditions after grazing on mountainous pasture (approximately 1,000 meters above sea level, in Nagano Prefecture) during the rearing period and ten Holstein steers ( $\mathrm{PH}$ group) were kept housed on low land from rearing to finishing. The growth and development of these animals during the rearing and finishing periods were almost similar to these reported in a previous paper ${ }^{5)}$. The final weight of the animals ranged from $520 \mathrm{~kg}$ to $630 \mathrm{~kg}$. 
The animals were kept two days without food and water, and then were slaughtered at the Grassland Research Institute. The steers were then dressed as in normal practice. Head, hide, tail, feet, diaphragma, lungs, heart, liver, ruminoreticulum, omasum, abomasum, small intestines, large intestines, kidney, omentum and offal fat (including stomach fat and omentum fat) were removed and weighed. The hot carcass weight was determined about one hour after slaughter, with kidney knob and channel fat included. Following this, the carcasses were placed at $4^{\circ} \mathrm{C}$ for 4 days. The left side was cut into joints and dissected physically into lean, fat and bone, and each portion was weighed. The longissimus thoracic muscle (from the 9 th to 10 th thoracic vertebrae section) from the right side was used for analyses of moisture, crude fat, total nitrogen, total pigments and shear value by the usual methods ${ }^{4}$.

\section{Results}

Table 1 shows the means and standard deviations of the weights of body components, and organs of the MG and $\mathrm{PH}$ groups. The average weights of heart, spleen,

Table 1. Means and standard deviations of organ weights in fattened steers, which were either housed ( $\mathrm{PH}$ group) or grazed on mountainous pasture (MG group) during their rearing period

\begin{tabular}{|c|c|c|c|}
\hline \multirow{2}{*}{ Item } & PH group & MG group & \multirow{2}{*}{ Significance } \\
\hline & Mean SD & Mean & \\
\hline (days) & $587.8 \pm 32.0$ & $750.1 \pm 101.1$ & $\mathrm{P}<0.01$ \\
\hline Slaughter weight & $573.2 \pm 37.2$ & $571.9 \pm 30.6$ & NS \\
\hline Hot carcass weight $(\mathbf{k g})$ & $341.5 \pm 14.0$ & $344,2 \pm 27,3$ & N S \\
\hline Carcass dressing & $59.7 \pm 2.6$ & $60.1 \pm 2.0$ & N S \\
\hline Hide & $39.0 \pm 3.0$ & $37.8 \pm 2.4$ & NS \\
\hline Head & $19.1 \pm 1.1$ & $20.3 \pm 1.1$ & $\mathrm{NS}$ \\
\hline$(\mathrm{kg})$ & $1.8 \pm 0,4$ & $1.8 \pm 0.5$ & NS \\
\hline Feet & $10.0 \pm 1.0$ & $10.6 \pm 0.5$ & N S \\
\hline Diaphragma & $3.3 \pm 0.5$ & $4.5 \pm 0.7$ & $\mathbf{P}<0.01$ \\
\hline Lungs & $3.6 \pm 0.4$ & $3.7 \pm 0.3$ & N S \\
\hline Heart & $2.1 \pm 0.3$ & $2.6 \pm 0.2$ & $\mathrm{P}<0.01$ \\
\hline Liver & $6.4 \pm 0.5$ & $6.2 \pm 1.0$ & NS \\
\hline Spleen & $1.2 \pm 0.2$ & $1.6 \pm 0.4$ & $\mathrm{P}<0.01$ \\
\hline Ruminoreticulum & 8. $1 \pm 1.2$ & $9.2+1.3$ & NS \\
\hline Omasum & $2.5 \pm 0.6$ & $3.3 \pm 0.6$ & NS \\
\hline Abomasum & $1.7 \pm 0.3$ & $2.0 \pm 0.3$ & $P<0,05$ \\
\hline Stomachs ${ }^{2}$ & $12.3 \pm 1.4$ & $14.5 \pm 1.6$ & $\mathrm{P}<0.01$ \\
\hline Small intestines & $7.8 \pm 2.7$ & $5.4 \pm 0.9$ & $P<0.05$ \\
\hline Large intestines & $3.7 \pm 2.0$ & $3.1 \pm 0.4$ & NS \\
\hline Kidney & $0.6 \pm 0.1$ & $0.7 \pm 0.1$ & N S \\
\hline Omentum & $17.9 \pm 4.0$ & $13.3 \pm 3.3$ & $P<0.05$ \\
\hline Offal fat & $43.6 \pm 9.9$ & $43.2 \pm 9.5$ & N S \\
\hline
\end{tabular}

NS not significant. a Stomachs includes ruminoreticulum, omasum and abomasum. ' ${ }^{b}$ Offal fat includes stomach fat and omentum. 
Table 2. Means and standard deviations of half carcass component weights in fattened steers, which were either housed ( $\mathrm{PH}$ group) or grazed on mountainous pasture (MG group) during their rearing period

\begin{tabular}{|c|c|c|c|c|}
\hline \multirow{2}{*}{ Item } & & PH group & MG group & \multirow{2}{*}{ Significance } \\
\hline & & Mean SD & Mean SD & \\
\hline Lean & $(\mathrm{kg})$ & $89.2 \pm 4.7$ & $89.7 \pm 6.6$ & N S \\
\hline Fat $^{\sharp}$ & $(\mathrm{kg})$ & 48. $5 \pm 2.4$ & 49. $2 \pm 8.8$ & N S \\
\hline Bone & $(\mathrm{kg})$ & $24.8 \pm 1.6$ & $27.2 \pm 1.5$ & $\mathrm{P}<0.01$ \\
\hline Kidney fat & (kg) & $8.9 \pm 1.1$ & $8.8 \pm 2.1$ & N S \\
\hline
\end{tabular}

NS not significant. ${ }^{\mathrm{a}}$ Fat includes kidney fat.

Table 3. Means and standard deviations of chemical composition and shear value of muscle in fattened steers, which were either housed ( $\mathrm{PH}$ group) or grazed on mountainous pasture (MG group) during their rearing period

\begin{tabular}{|c|c|c|c|c|}
\hline \multirow{2}{*}{ Item } & & PH group & MG group & \multirow{2}{*}{ Significance } \\
\hline & & Mean SD & Mean SD & \\
\hline Moisture & $(\%)$ & $72.0 \pm 1.7$ & $71.5 \pm 1.8$ & N S \\
\hline Crude fat & (\%) & $5.1 \pm 2.4$ & $6.1 \pm 2.0$ & NS \\
\hline Total nitrogen & $(\%)$ & $3.4 \pm 0.2$ & $3.4 \pm 0.1$ & N S \\
\hline Total pigments & $(\mathrm{mg} \%)$ & $23.0 \pm 2.8$ & $23.4 \pm 3.2$ & N S \\
\hline Shear value & $\left(\mathrm{lb} / \mathrm{cm}^{2}\right)$ & $13.9 \pm 3.2$ & $11.7 \pm 2.7$ & N S \\
\hline
\end{tabular}

NS not significant.

diaphragma and stomachs of the MG group were significantly larger than those of the PH group $(\mathrm{P}<0.01)$. On the other hand, the small intestines and omentum of the $M G$ group were significantly lighter than those of the $\mathrm{PH}$ group $(\mathrm{P}<0.01)$. The average hot carcass weight and dressing percentage were slightly greater and higher in the MG group than those in the PH group.

Table 2 shows the means and standard deviations of the half carcass component weights of the MG and PH groups. The average bone weight of the MG group was significantly greater than that of the $\mathrm{PH}$ group $(\mathrm{P}<0.01)$. The average lean and fat weights of the two groups were almost equal.

Table 3 shows the longissimus muscle composition of the MG and PH groups. There were no significant differences between them.

\section{Discussion}

The weights of heart, spleen and diaphragma of the MG group were significantly greater than those of the PH group $(\mathrm{P}<0.01)$. These differences in weights of heart and spleen have been reported by SAwazaki $e t$ al. ${ }^{10)}$, who made a comparison of Japanese Black, Japanese Shorthorn and Hereford steers under housed and grazed conditions. In their study, they considered these differences were caused by adaptation 
to mountainous rearing environments such as low ambient pressure, low oxygen tension and cold atmosphere. They also considered that grazing on slopes influenced the weight of organs. SAWAzAKI has reported that the weight of the heart increased in mice exposed to high altitudes ${ }^{11}$. In the present work, the authors obtained results similar to the findings of SAWAZAKI and his colleagues, and concluded that the heart and spleen of the MG group were influenced by the mountainous environment.

As shown in Table 1, the differences between the MG and PH group in weights of hide, head, tail, feet, lungs, liver, ruminoreticulum, omasum, large intestines, kidney and offal fat, were not statistically significant. The weights of the abomasum $(\mathrm{P}<$ $0.05)$, stomachs $(\mathrm{P}<0.01)$, being heavier in the $\mathrm{MG}$ group than in the $\mathrm{PH}$ group, small intestines $(\mathrm{P}<0.05)$ and omentum $(\mathrm{P}<0.05)$, being lighter in the $M G$ group than in the PH group, were statistically different between the groups. It may be considered that the differences in the weights of each organ were influenced not only by mountainous environment but also by age, because the steers in the MG group showed a slower growth rate during the mountainous grazing period than the steers in the $\mathrm{PH}$ group, as noted in our previous report ${ }^{5}$. IMAIZUMI $^{6}$ ) and Pálsson and VERGÉS ${ }^{12}$ have reported that development of organs such as abomasum, stomachs, oma* sum, small intestines in cattle and in sheep was affected by level of nutrition and age.

It is interesting to note that both stomachs and diaphragma were heavier in the MG group than in the PH group. It may be concluded that there is some relationship between stomachs and diaphragma.

No significant difference was ascertained in dressing percentages between the MG and $\mathrm{PH}$ groups. However, the dressing percentage of the MG group was slightly higher than that of the $\mathrm{PH}$ group. On the other hand, SAWAzAKI et al. ${ }^{10)}$ reported that the dressing percentage in Japanese Black cattle reared in mountainous regions was significantly higher than those reared at sea level. This difference in the dressing percentage between the present study and the results reported by SAWAZAKI et al.10) may be due to the differences in type and breed. The dressing percentage of beef cattle was higher than that of dairy cattle, as noted by OKaDA et $a l^{2}{ }^{2}$. It may also be related to the stage of maturity of the animals at slaughter.

Regarding the carcass composition, there were no differences in the weights of lean and fat between the MG and PH groups, while the total bone weight of the MG group was significantly greater than that of the $\mathrm{PH}$ group $(\mathrm{P}<0.01)$. This difference in bone weight appeared to be due to the influence of the mountainous environment.

Winchester and Ellis, who conducted an experiment on the delayed growth of

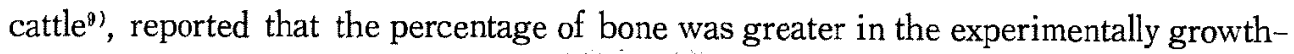
delayed animals than in the controls. "They concluded that this was more likely due to the greater age at slaughter than to the nutritional status at the early growth stage. It is also reported that higher correlation coefficients were obtained between bone weight and age than between bone weight and live weight ${ }^{81}$. Therefore, the bone of the MG group, being heavier than in the $\mathrm{PH}$ group, was thought to be influenced not only by mountainous environment but also by age. 
There was no significant difference in fat content between the MG and PH groups. However, the crude fat content of the MG group was slightly larger than that of the PH group. SaWAzaki et al. ${ }^{10)}$ reported that the marbling score in groups reared in mountainous regions was higher than those in groups reared at sea level. In general, the marbling score relates to fat content in the longissimus muscle and a higher marbling score has more fat content in the muscle ${ }^{7}$. This difference in fat content between the results of this study and the results reported by SwaWAzAKI et al. ${ }^{10}$ may be due to the differences in type and breed, involved as it is with the dressing percentage.

It was deduced that grazing in mountainous regions during the rearing period influenced feeder cattle in the weights of organs like spleen, diaphragma, heart and stomachs and on bone after finishing. However, it was concluded that the chemical and physical properties of meat of finished cattle were almost the same when compared on the same weight basis, in spite of different rearing environments.

\section{Acknowledgements}

We are grateful to Dr. Y. Ohyama of the National Grassland Research Institute for his helpful suggestions in drafting this paper.

\section{References}

1) Ozutsumi, K., M. Okada and N. Kawakami, Bull. Natl. Grassl. Res. Inst., 9: 49-56. 1976.

2) Okada, M., N. Kawakami, K. Ozutsumi and A. Shinohara, Bull. Natl. Grassl. Res. Inst., 7: $121-130.1975$.

3) Okada, M., N. Kawakami and K. Ozutsumi, Bull. Natl. Grassl. Res. Inst., 10: 111-119. 1977.

4) Ozutsumi, K., M. Okada, N. Kawakami and T. Yamazaki, Bull. Natl. Grassl. Res. Inst., 17: $99-105.1980$.

5) Ozutsumi, K. and M. OKadA, Jpn. J.Zootech. Sci., 52: 741-748. 1981.

6) Imaizumt, E., Res. Bull. Hokkaido Natl. Agric. Exp. Stn. 125: 85-159. 1980.

7) Takeshita, K., S. Tanaka and S. Yoshida, Res. Bull. Tohoku Natl. Agric. Exp. Str., 43: 209-223. 1972.

8) Guenther, J. J., D. H. Bushman, L. S. Pope and R. D. Morrison, J. Anim. Sci., 24: 11841191. 1965.

9) Winchester, C.F. and N. R. Ellis, Tech. Bull. USDA. No. 1159: 1-26. 1957.

10) Sawazaki, H., H. Hirose, T. Kikuchl, T. Kruma, S. Takizawa, M. Takahashi, M. Fuchimukal, T. Onodera, S. Saito, G. Katabira and U. Yoshida, Jpn. J. Zootech. Sci., 46: 469-476. 1975.

11) SaWazaki, H., Jpn. J. Zootech. Sci, 43: 719-725. 1972.

12) PÁlsson, H. and J. B. Vergés, J. Agric. Sci., 42: 93-149. 1952. 
Ozutșumi, Okada, Yamazaki, Kawakami and Usui

\title{
山岳育成が肥育牛の器官, 枝肉おょび \\ 肉組成に及ぼす影響
}

\author{
小堤菱平 - 岡田光男 ${ }^{*}$ - 山崎敏雄 ・ \\ 河上尚実・白井 実
}

農林水産省草地試験場, 杤木県西那須野町 329-27

带広畜産大学，帯広市 080

山岳育成が肥育牛に及ぼす影響を調べるために，山岳 地带で育成し，その後平場で肥育したホルスタイン種去 勢牛 11 頭と, 平場で育成・肥育したホルスタイン種去勢 牛 10 頭について, それぞれの諸器官重量, 枝肉組成拧 よび肉組成について比較検討した。これらの牛の屠殺前 体重は約 $600 \mathrm{~kg}$ であり，結果は次の通りであった。山 岳育成した肥育牛の心臟, 脾蔵, 横隔膜求よび複胃の平 均重量社平地で充成した肥育牛よりむ有意に大きかった
$(\mathrm{P}<0.01)$ が，小腸拉よび大網膜の平均重量は平場で育 成した肥育牛の方が山岳で育成した肥育生よりむ有意に 大きかった $(\mathrm{P}<0.05)$ ，枝肉中の笳肉および脂肪の平 均重量は再者間に差はなかったが，山岳で育成した肥育 牛の平均骨量は平場で䏍成した肥育牛より有意に大き かった $(\mathrm{P}<0,01)$ ，笳肉の組成には两者間で有意な差は 認められなかった。

口畜会報， $53(8) ： 553-558 ， 1982$ 